\title{
Editorial
}

\section{A gene signature of loss of oestrogen receptor (ER) function and oxidative stress links ER-positive breast tumours with an absent progesterone receptor and a poor prognosis}

\author{
Patrick Neven, Toon Van Gorp and Karen Deraedt
}

Multidisciplinary Breast Centre and Gynaecological Oncology, UZ Leuven, Campus Gasthuisberg, Herestraat 49, B - 3000 Leuven, Belgium

Corresponding author: Patrick Neven, patrick.neven@uz.kuleuven.ac.be

Published: 4 September 2008

Breast Cancer Research 2008, 10:109 (doi:10.1186/bcr2135)

This article is online at http://breast-cancer-research.com/content/10/5/109

(c) 2008 BioMed Central Ltd

See related research article by Yau and Benz, http://breast-cancer-research.com/content/10/4/R61

\begin{abstract}
Prognostic gene signatures like the wound and hypoxia signature differ by assumptions of cellular growth. Although gene signatures show little overlap, they also track within the group of luminal breast tumours those with a high proliferation and poor prognosis. Oxidative stress is another assumption of cellular growth. It affects several pathological conditions through its influence on the regulation of protein kinases and signal transduction pathways. A comprehensive set of 62 core genes from cultured oestrogen- and oestrogen receptor-deprived epithelial breast cancer cells is responsive to three forms of oxidative stress. Evidence is presented that oxidative stress involves the development of an aggressive subset of primary oestrogen receptor-positive breast tumours.
\end{abstract}

An imbalance between pro-oxidants and antioxidants can lead to a state of oxidative stress. Yau and Benz [1] studied the subset of oestrogen (E)-responsive genes susceptible to modulation by oxidative stress. They identified an overlapping set of 891 E-related and oestrogen receptor (ER)-related probes in the MCF-7 ER ${ }^{+}$breast cancer cell line associated with loss of $E$ and $E R \alpha$ function (E/ER signature). They further compared the genes involved in this E/ER signature with probes from two different MCF-7 cell lines modulated by oxidative stress: (a) MCF-7 controls (Ox signature) and (b) MCF-7 cell lines with ER $\alpha$ knockdown (Ox' signature) leading to, respectively, the $O x-E / E R$ signature and $O x^{\prime}-E / E R$ signature. The $\mathrm{Ox}-\mathrm{E} / \mathrm{ER}$ signature is a set of 62 unique genes, 46 of which are connected within networks linked through various kinases and growth factors (19) and oxidative signalling (16) and cell motility (11) pathways. Some of the genes in the signatures also imply, not surprisingly, that oxidative stress is associated with an impaired tumour necrosis factor-nuclear factor-kappa-B cell survival-death pathway and variable endocrine responsiveness of $\mathrm{ER}^{+}$ breast tumours.

Only a third of genes involved in loss of ER function overlap with E-induced genes in MCF-7 breast cancer cells [2], which suggests that $E$ withdrawal and ER function loss are not entirely reciprocal conditions relative to $E$ stimulation. Only $8 \%$ of probes involved in ER function loss were affected by all oxidants, including $\mathrm{Bcl} 2$ but not progesterone receptor (PR) and GREB1, implying that PR loss is only a partial surrogate for increased oxidative stress [3]. Although there is little gene overlap with the prognostic molecular profile of $\mathrm{ER}^{+} / \mathrm{PR}^{-}$tumours in the luminal $\mathrm{B}$ subset as defined by Perou and colleagues [4] and Creighton and colleagues [5], these findings confirm that oxidative stress may be intrinsic to the highly proliferative subtype of luminal tumours [6]. Though $\mathrm{ER}^{+}$, they may be functionally analogous to $\mathrm{E}$-independent breast tumours. They are also likely to show less sensitivity to hormonal therapies. These observations are synergistic with the known effects of oxidative stress in impairing ER functions related to DNA binding and transactivation in up to a third of $\mathrm{ER}^{+}$breast tumours which correlated with loss of PR expression and a tamoxifen-resistant phenotype $[7,8]$.

In $\mathrm{ER}^{+}$breast tumours, those with a high grade, those that are $\mathrm{PR}^{-}, \mathrm{HER}_{-} 2^{+}$, and those with a higher expression of proliferative genes as seen in young women were associated with the oxidative stress gene signature. Increasing age at breast cancer diagnosis was - surprisingly - not related to an enrichment of oxidative stress markers, again showing evidence that loss of PR with age is more than increased oxidative stress, which has already been suggested by others $[9,10]$. Our findings of an age-dependent association

$\mathrm{E}=$ oestrogen; $\mathrm{ER}=$ oestrogen receptor; $\mathrm{PR}=$ progesterone receptor. 
between HER-2 amplification and PR loss in $\mathrm{ER}^{+}$tumours might be explained by this biologic trait [11].

To ascertain the role of oxidative stress in breast cancer prognosis, the authors associated the five derived gene signatures and four other reported gene signatures, including sustained $\mathrm{E}$ induction, luminal subtype, MAPK (mitogen-activated protein kinase) induced/repressed, and tumour proliferation studied with follow-up data in a pooled set of $394 \mathrm{ER}^{+}$primary breast tumours. The poor clinical outcome associated with the expression of the 'Ox-E/ER' signature in this manuscript is in agreement with previously published work [6]. Also, an association between a nonfunctioning NQO1 enzyme - which in normal circumstances protects against oxidative stress - and an adverse breast cancer outcome was recently described [12]. We also know from the clinic that women with an $\mathrm{ER}^{+}$ breast tumour do worse if the tumour lacks PR or overexpresses HER-2 [13,14]. That the gene signature outperformed the prognostic model achieved by the PR status alone may be related to several factors. We have already suggested an age-related association between PR loss and HER-2 overexpression in ER+ breast tumours [15] and we suggest an interaction between oxidative stress, age at breast cancer diagnosis, and PR expression. Yau and Benz need to further explore whether their prognostic model still outperforms the expression of PR as a prognostic marker stratifying for age at diagnosis.

This study is a first look into the possible association between oxidative stress, loss of ER function, PR expression, and poor prognostic breast cancer phenotypes. Extending this concept to other $\mathrm{ER}^{+}$breast cancer cell lines with oxidising agents would have strengthened this work tremendously but should encourage others to explore this area. This gene list is far from being a clinical test. Whether any of the tested microarray gene expression profiling for breast cancer prognosis is better than an optimised panel of clinical, objectively measured, prognostic markers remains an open question and currently is being explored in prospectively designed clinical trials. Although the oxidative stress phenotype is associated with a poor disease outcome, Yau and Benz did not address the effect of treatment data. Because radiation and chemotherapy like anthracyclines influence oxidative processes and DNA repair, accounting for treatment effects in any study design is a requirement. If oxygen radicals do lead to a poorer prognosis, antioxidants like carotenoids (for example, $\alpha$-carotene, $\beta$-carotene, lutein, zeaxanthin, $\beta$ cryptoxanthin, and lycopene) and vitamins $C$ and $E$ may be of therapeutic value, although such an approach does not seem to work for $\mathrm{ER}^{+} / \mathrm{PR}^{-}$lesions $[16,17]$. This, however, remains an exciting possibility also for $\mathrm{PR}^{+}$lesions because wellchosen antioxidants are of low toxicity.

\section{Competing interests}

The authors declare that they have no competing interests.

\section{Acknowledgement}

The authors thank Evi Laeremans for editing.

\section{References}

1. Yau C, Benz CC: Genes responsive to both oxidant stress and loss of estrogen receptor function identify a poor prognosis group of ER-positive primary breast cancers. Breast Cancer Res 2008, 10:R61.

2. Oh DS, Troester MA, Usary J, Hu Z, He X, Fan C, Wu J, Carey LA, Perou CM: Estrogen-regulated genes predict survival in hormone receptor-positive breast cancers. J Clin Oncol 2006, 24:1656-1664.

3. Liang X, Lu B, Scott GK, Chang CH, Baldwin MA, Benz CC: Oxidant stress impaired DNA-binding of estrogen receptor from human breast cancer. Mol Cell Endocrinol 1998, 146:151161.

4. Perou CM, Sørlie T, Eisen MB, van de Rijn M, Jeffrey SS, Rees CA, Pollack JR, Ross DT, Johnsen H, Akslen LA, Fluge O, Pergamenschikov A, Williams C, Zhu SX, Lønning PE, Børresen-Dale AL, Brown PO, Botstein D: Molecular portraits of human breast tumours. Nature 2000, 406:747-752.

5. Creighton CJ, Kent Osborne C, van de Vijver MJ, Foekens JA, Klijn JG, Horlings HM, Nuyten D, Wang Y, Zhang Y, Chamness GC, Hilsenbeck SG, Lee AV, Schiff R: Molecular profiles of progesterone receptor loss in human breast tumors. Breast Cancer Res Treat 2008 Apr 19. [Epub ahead of print].

6. Dairkee SH, Nicolau M, Sayeed A, Champion S, Ji Y, Moore DH, Yong B, Meng Z, Jeffrey SS: Oxidative stress pathways highlighted in tumor cell immortalization: association with breast cancer outcome. Oncogene 2007, 26:6269-6279.

7. Scott GK, Kushner P, Vigne JL, Benz CC: Truncated forms of DNA-binding estrogen receptors in human breast cancer. $J$ Clin Invest 1991, 88:700-706.

8. Schiff R, Reddy P, Ahotupa M, Coronado-Heinsohn E, Grim M, Hilsenbeck SG, Lawrence R, Deneke S, Herrera R, Chamness GC, Fuqua SA, Brown PH, Osborne CK: Oxidative stress and AP-1 activity in tamoxifen-resistant breast tumours in vivo. $J$ Natl Cancer Inst 2000, 92:1926-1934.

9. Quong J, Eppenberger-Castori S, Moore D 3rd, Scott GK, Birrer MJ, Kueng W, Eppenberger U, Benz CC: Age-dependent changes in breast cancer hormone receptors and oxidant stress markers. Breast Cancer Res Treat 2002, 76:221-236.

10. Cui X, Schiff R, Arpino G, Osborne CK, Lee AV: Biology of progesterone receptor loss in breast cancer and its implications for endocrine therapy. J Clin Oncol 2005, 23:7721-7735.

11. Huang $H J$, Neven $P$, Drijkoningen M, Paridaens R, Wildiers $H$, Van Limbergen E, Berteloot P, Amant F, Vergote I, Christiaens MR: Association between tumour characteristics and HER-2/neu by immunohistochemistry in 1362 women with primary operable breast cancer. J Clin Pathol 2005, 58:611-616.

12. Fagerholm R, Hofstetter B, Tommiska J, Aaltonen K, Vrtel R, Syrjäkoski K, Kallioniemi A, Kilpivaara O, Mannermaa A, Kosma VM, Uusitupa M, Eskelinen M, Kataja V, Aittomäki K, von Smitten K, Heikkilä P, Lukas J, Holli K, Bartkova J, Blomqvist C, Bartek J, Nevanlinna $\mathrm{H}$ : NAD(P)H:quinone oxidoreductase $1 \mathrm{NQ}^{*} 2$ genotype (P187S) is a strong prognostic and predictive factor in breast cancer. Nat Genet 2008, 40:844-853.

13. Banerjee M, George J, Song EY, Roy A, Hryniuk W: Tree-based model for breast cancer prognostication. J Clin Oncol 2004, 22:2567-2575.

14. Brouckaert O, Pintens S, Van Belle V, Van Huffel S, Camerlynck $E$, Amant $F$, Leunen $K$, Smeets A, Berteloot $P$, Van Limbergen $E$, Decock J, Hendrickx W, Weltens C, Van den Bogaert W, Vanden Bempt I, Drijkoningen M, Paridaens R, Wildiers H, Vergote I, Christiaens MR, Neven P: Short-term outcome of primary operated early breast cancer by hormone and HER-2 receptors. Breast Cancer Res Treat 2008 Jul 16. [Epub ahead of print].

15. Huang $H J$, Neven $P$, Drijkoningen M, Paridaens R, Wildiers $H$, Van Limbergen $E$, Berteloot $P$, Amant $F$, Christiaens MR, Vergote I: Association between HER-2/neu and the progesterone receptor in oestrogen-dependent breast cancer is age-related. Breast Cancer Res Treat 2005, 91:81-87.

16. Gaudet MM, Britton JA, Kabat GC, Steck-Scott S, Eng SM, Teitelbaum SL, Terry MB, Neugut Al, Gammon MD: Fruits, vegetables, and micronutrients in relation to breast cancer modified by menopause and hormone receptor status. Cancer Epidemiol Biomarkers Prev 2004, 13:1485-1494. 
17. Cui Y, Shikany JM, Liu S, Shagufta Y, Rohan TE: Selected antioxidants and risk of hormone receptor-defined invasive breast cancers among postmenopausal women in the Women's Health Initiative Observational Study. Am J Clin Nutr 2008, 87:1009-1018. 